\title{
DEVIRES SONOROS revolucionários em Deus e o Diabo na Terra do sol
}

Andrigo de Lázaro o. Casé do Nascimento (UFBA)

\section{Introdução}

O processo de transformação do fazer cinematográfico, a partir do final da segunda guerra mundial, emana da falência do formato dos grandes estúdios fora dos EUA e da invenção de novos modelos de criação e produção de expressões fílmicas independentes. O nascimento de novas cinematografias modernas se dá em muitos lugares ao redor do mundo motivado pelo desafio que novos autores se propóem de libertar-se dos paradigmas estéticos do filme narrativo dominante.

No Brasil do início dos anos de 1960, o realismo dramático do cinema mainstream convencional é minado. Novos diretores entusiasmados pela atmosfera dos cineclubes, onde mantinham contato com cinematografias autorais e com filmes das vanguardas artísticas europeias compensam a escassez de recursos técnicos usando o excesso como estratégia. Promovem uma subversão ruidosa, contrapondo-se ao ascetismo estético do cinema industrial. Rejeitam a harmonia e a unidade formais em prol da assimetria, do heterogêneo, da multiplicidade, assumindo uma estética convulsiva e rebelde. Mobilizam o tema da fome para contrapor-se ao discurso moralizador do regime militar, de uma maneira crítica. 
Os filmes da primeira fase do Cinema Novo, mais especificamente os da chamada Trilogia do sertâa ${ }^{1}$, se alinham às práticas de resistência artística que iniciam uma resposta franca aos valores conservadores do discurso militar de modernização. Ultrapassam as convençôes formais do realismo dramático e promovem um devoramento antropofágico de vários estímulos da cultura sertaneja em sua heterogeneidade. Rompem com as convençóes lineares e de causa e efeito da poética aristotélica, sacralizadas pelo cinema hegemônico norte-americano. Estimulam uma nova sensibilidade fílmica em vez de domesticá-la, sugerindo novos territórios sonoros cinematográficos, desestabilizadores das noções totalizantes do som vindas do cinema narrativo hollywoodiano.

Ao retornar a ambiência sonora sertaneja e redimensioná-la através do cinema, os diretores do Cinema Novo experimentam uma espécie de “disjunção” visual-sonora, onde os sons se elevam e ganham autonomia expressiva, passando a nos afetar de maneira diferenciada ao interagir com as imagens. Ao mesmo tempo em que passam a recriar a utilização dos sons no cinema brasileiro, os filmes da trilogia mobilizam escutas fílmicas acostumadas aos territórios sonoros cinematográficos hegemônicos. Antecipam a criação de novos territórios sonoros diferenciados, que irá se intensificar com o surgimento de novos movimentos artísticos na música e no próprio cinema, potentes o suficiente para criar novos modos de escuta. A operação realizada por esses filmes reinventa sonoridades da cultura local, destravando devires sonoros no cinema brasileiro, que reverberam seus deslizamentos estéticos e encontram eco em movimentos artísticos posteriores, em autores criativos do cinema e da musica brasileira, que passam a destravar devires sonoros ao repetir, de maneira diferenciada, a estratégia criativa utilizada pelos primeiros filmes do Cinema Novo.

\section{Contexto dos sons eztetykos}

O Cinema Novo nasce da necessidade de criar outro cinema, de inventar um novo país, de problematizar seus desafios, tencionar suas contradiçóes, ressoar linhas de fuga, afirmar o pensamento de autores preocupados em fazer da arte cinematográfica uma potência expressiva sensível à realidade, ao mesmo tempo política, ética e criativa. Devir estético revolucionário em uma zona de combate.

O mercado de produção nacional de filmes entrara em crise em 1954, após a frustrada tentativa dos estúdios Vera Cruz de impor e manter um cinema de modelo industrial, pautado pelas técnicas e práticas do cinema mercadológico europeu e norte-americano, e alinhado às pretensóes nacionalistas de posicionar o país na trilha do capitalismo internacional. Atravessados pela situação sociopolítica brasileira e da Amé- 
rica do Sul, no início da década de 1960, os diretores do Cinema Novo, em sintonia com as propostas de produçáo do cinema neorrealista italiano e de outras vanguardas cinematográficas, munidos de equipamentos mais baratos e mais práticos, vão para as ruas filmar as histórias do povo. Viajam pelo interior do país, para o sertão nordestino, e inauguram uma lógica de produção nômade, anti-imperialista, ainda no período Janio/ Jango que antecede o golpe de 64. Essa atitude, além de viabilizar uma produção mais livre e mais inventiva, sem a tirania de um produtor centralizador, teria a intenção de promover um desmanche das estratégias de dominação políticas e culturais que estavam sendo implementadas pelo projeto de modernização nacionalista-capitalista, iniciado por Juscelino Kubitschek, o "presidente bossa-nova", que culminou no golpe militar de 31 de março de 1964.

Faz-se importante ampliar a interpretação sobre as estratégias de manutenção da ordem econômica, política e cultural, implementadas pelos militares e seu aparelho de Estado naquele contexto, que para legitimar a violência e a perseguição às vozes subversivas, amplificava a inserção do seu poder para além das condições objetivas de apreensão da realidade, passando a construir subjetividades cúmplices de seus interesses de dominação, conquistando a adesão da opinião pública ante os atos de perseguição, repressão e censura, que passavam a ser aceitos como necessários para coibir o que era considerado inadequado aos valores da moral e da ordem, propalados e construídos pelo discurso de dominação. $\mathrm{O}$ discurso dos militares convergia para uma visão unificada do Brasil, padronizada, edificava mitos morais que deveriam ser respeitados e preservados a todo custo, como o respeito à família, à propriedade privada e ao Estado. O enraizamento de valores conservadores, restituídos como essenciais, a manutenção de relaçóes socioeconômicas arcaicas, como as do paternalismo agrário e seus latifúndios, a manipulação da realidade pelos meios de comunicação favoráveis ao golpe e financiados pelo capital norte-americano ${ }^{2}$, o silêncio sobre as mortes e as torturas, a vigilância e o controle eram táticas imbricadas que validavam o estado de exceçáo, que tornava a perseguição aos subversivos, consenso fabricado. Para a burguesia comercial local e para as multinacionais norte-americanas, que eram parte fundamental do projeto de modernização, o que importava era a ampliação do mercado consumidor, para isso era necessário integrar a nação, unificar os interesses desenvolvimentistas. É criada a TV Globo, empresa de telecomunicação financiada pelo capital estrangeiro, concedida pelo Estado militar ao então diretor do jornal O Globo, Roberto Marinho. O Globo e outros jornais como O Estado de São Paulo, Folha de São Paulo, Jornal do Brasil e o Correio da Manhã estampam na época manchetes de capa favoráveis ao golpe de 1964. Recentemente O Globo reconheceu em editorial o apoio aos militares, mesmo 
tentando embaçar o contexto e a real ligação dos empresários da comunicação com os interesses golpistas ${ }^{3}$.

O regime de exceção, aliado ao setor empresarial e aos grandes proprietários de terra, promovia um esquema de fabricação de verdades para agenciar subjetividades cúmplices. Através dos meios de comunicação e dos mecanismos oficiais de propaganda, faziam a opinião pública aceitar, acreditar e reproduzir o discurso de que o único caminho para a transformação do país seria modernizá-lo. A difusão de padróes de consumo, de desejos e de comportamentos, aceitos e assimilados como símbolos da benesse capitalista, funcionava como tática de sedução e cooptação, um terreno propício para a fundação dos mitos modernos de integração nacional, do bem comum ou bem estar social, forjados pela euforia do milagre econômico militar, alinhado à ampliação do mercado da cultura de massas norte-americano na América do Sul. Esses mitos precisavam ser edificados para justificar as açôes do Estado, que continuava a "codificar seus membros pela relação de obediência e transgressão." "Espalham a paranoia anticomunista, anunciam suas diretrizes, regras e leis, preocupando-se exclusivamente em atender aos interesses políticos e financeiros dos integrantes do pacto modernizador. Todos deviam acreditar que seriam inclusos no projeto de modernização, aceitá-lo tornara-se um dever patriótico, moral, que traria recompensas e realizaçôes, mesmo que para isso fosse necessário sujeitar-se, para tornar-se útil ao empreendimento:

É por isso que o Estado é um grande estimulador e reprodutor das paixões tristes, como diz Espinosa. É por medo dos castigos e esperança das recompensas que o indivíduo submete-se a um poder que o separa da sua própria capacidade de agir e pensar livremente, desejando sua própria servidão. (FUGANTI, 2013, p.1).

Por outro lado, as vozes dissonantes que atravessavam os regimes de poder provocavam fissuras, expondo as fragilidades da fundação do empreendimento ditatorial. Naquela conjuntura, os múltiplos movimentos de resistência, inclusive armada, pretendiam reverter a situação, fazer vir a baixo a ditadura e o capitalismo internacional. Para isso se organizavam em diversas estratégias de atuação. Não havia uma centralidade que coordenasse as açóes dos vários movimentos rebeldes que coexistiam. O panorama era dissonante e a resistência se empenhava na tentativa de sabotar o projeto de modernidade, contrapondo-se ao poder do aparelho estatal.

Os diretores do Cinema Novo e seus filmes faziam parte da resistência ao modelo de governo autoritário nos anos de 1960 e às suas práticas de "controlar-reprimir e controlar-estimular", especialmente no campo de combate da cultura e da arte. Empenhavam-se em levar às telas a violência dos acontecimentos sociais, relacionando-os 
às ambiguidades do processo político. Ao passo que refletiam sobre as contradiçóes do projeto modernizador, intensificadas, entre outras coisas, por apelos ao consumo de mercadorias da cultura de massas norte-americana, incompatíveis com a realidade material da maioria da população brasileira e pela manutenção da violência e da pobreza no campo, os autores criavam novos paradigmas técnicos e estéticos, desmistificadores das convençôes e estilos ligados a um modelo de expressão fílmica mercadológico, burguês, capitalista, que servia aos interesses econômicos da dominação.

Para nós o que particularmente interessa, desse desmonte criativo revolucionário promovido pelos filmes da primeira fase do Cinema Novo é a forma como esse cinema reinventa o uso dos sons na montagem fílmica, de modo a afirmar a sua potência sensível como um dos fortes elementos da Eztetyka da Fome ${ }^{5}$. Escolhemos abordar o som em Deus e o Diabo na Terra do Sol, como disparador de questóes diretamente relacionadas ao seu momento de produção e exibição, que acontece no auge da agitação social que tomava conta do mundo no início da década de 1960, em especial no Brasil e em toda a América do Sul.

\section{Subversão sonora fílmica}

O Estado Militar e seu projeto de integração nacional ganhavam força com a adesão dos empresários da indústria cultural, que o enxergavam a partir da formação de um mercado consumidor de massa integrado. Modos diferentes de ouvir conviviam sob a influência de um projeto político e cultural, impulsionado pelo capital estrangeiro norte-americano para ser desenvolvido pelos militares em parceria com a burguesia industrial. Era importante para os investidores e agentes da indústria cultural moldar sensibilidades e adequá-las ao consumo da cultura de massas, modulando gostos, sintonizando-os com os inúmeros apelos formadores de opinião que vinham do rádio, do cinema, e da TV, dispositivos sonoros construtores de Territórios Audíveis.

Iremos associar à nossa reflexão sobre os sons em Deus e o Diabo na Terra do Sol, o conceito de território desenvolvido por Gilles Deleuze e Félix Guatarri e discutido no livro Mil platôs: capitalismo e esquizofrenia Vol.4 (1979). O território para esses autores adquire valor existencial e expressivo, circunscreve espaços interiores protegidos do caos exterior, estabelece fronteiras, propriedades, domínios e subjetividades. Segundo eles um território não é algo dado, ele se constrói, suas características se expressam por atos, por meios qualitativos, por qualidades expressivas. O conceito de território em Deleuze e Guatarri está diretamente associado a termos como: desterritorialização, reterritorialização e ritornelo. Encontrar um abrigo seguro para nos proteger do caos é territorializar. Transgredir 
as fronteiras de um domínio, fazer viajar o pensamento, seria desterritorializar. Retornar a um abrigo seguro, a um confortável domínio, em alguns casos seria reterritorializar. Essas terminaçóes se inter-relacionam de forma dinâmica. Territórios para eles seriam matérias de expressão que se territorializam, delimitando espaços e domínios, simultaneamente propriedade e expressividade, dotados de componentes qualitativos produtores de meios, capazes de estabelecer marcas e posse ao mesmo tempo. São as matérias de expressão que emergem para fundar o território, passando a defini-lo. Elas se criam ao passo que traçam territórios. Os sons, os cheiros e as imagens são marcas expressivas capazes de delimitar territórios. A função de um território não vem primeiro que a sua potência expressiva, esta é quem se territorializa e funda o território:

Os territórios sonoros produzem entidades incorporais, transformações incorpóreas a partir dos fluxos sônicos. Eis algumas das potências do som: produzir tempos, ritornelos, ritmos, territórios existenciais e universais, subjetividades. (OBICI, 2008, p.100).

O som amplificado se propaga pelo meio elétrico e material, constituindo territórios sonoros, que podem ser sentidos como estados de afeto, placas sinalizadoras, pensamentos transitórios, sentimentos passageiros. Segundo Deleuze e Guatarri os meios vibram e interagem uns com os outros num fluxo que instaura territórios, locais de passagem que estabelecem domínios, distâncias entre os seres, gerando entradas e saídas, ritmos diferenciados que coabitam num mesmo meio, qualidades estéticas passageiras que tem urgência em criar territórios para escaparem do caos. ${ }^{6}$ Dizendo de outro modo, os componentes de um território sonoro são como atos expressivos, forças de expressão, que modificam o ambiente ao passo que fundam propriedade. Marcas que atravessam nossa matéria sensível provocando sensaçóes para além de suas potências de expressão:

A delimitação do território já é uma produção carregada de códigos que operam num jogo de territorialização e desterritorialização, algo parecido com a função das artes, que, de alguma forma, também criam territórios. Na urgência de criar um território, a arte se faz sem ter que esperar o homem para começar. $\mathrm{O}$ artista se arrisca numa aventura perigosa diante do caos, podendo ser todo descodificado, ao mesmo tempo em que descodifica. (OBICI, 2008, p. 77).

"Descodificar" para Deleuze e Guatarri significa transformar os códigos de um meio expressivo, diferente de Transcodificar que seria traspor códigos de um meio a outro. A arte estaria apta a simultaneamente transformar e ser transformada pelos territórios sonoros. Teria a condiçáo de criar novos territórios, outros mundos possíveis, uma profusão de mundos em devir. ${ }^{7}$ Provocar transformaçóes incorpóreas que colo- 
cam, no caso dos sons no cinema, todo o nosso corpo a ouvir. Os Territórios Sonoros dominantes propostos à época do golpe de 1964 faziam as subjetividades funcionarem articuladas à produção e ao consumo de mercadorias, contribuindo para a aceitaçáo do modelo de Estado autoritário. Como num sistema produtor de desejos, colonizador de sensibilidades, capaz de desconstruir, enfraquecer e capturar nosso potencial de escuta, gerando processos de subjetivação, para torná-lo útil a "um imperialismo da audição."

Consumir mercadorias, fabricar necessidades, seguir valores morais, aceitar o autoritarismo, docilizar os ouvidos, demandas atravessando o plano do sensível, da escuta, treinando as sensibilidades, viciando-as. O uso dos sons em Deus e o diabo rompe com padróes diegéticos convencionais (sons de dentro da história) quando alarga as fronteiras das convençóes estabelecidas para o uso do som no cinema, se desgarrando dos padróes, fazendo os sons habitarem mais o plano do sensível, numa relação com as imagens diferente daquelas encontradas nos filmes de narrativa clássica, onde o uso do som é altamente codificado, atrelado à continuidade narrativa. Em Deus e o Diabo na Terra do Sol o uso da música na trilha sonora é marcado pela mediação entre o cordel e Villa Lobos. Glauber Rocha inova e faz convergir sonoridades vindas de dois diferentes territórios sonoros, sons que não eram comuns aos filmes brasileiros até aquele momento. Ao unir a força da oralidade do cordel com a música erudita inovadora feita por Villa Lobos, Glauber promove uma interação entre meios musicais distintos, provocando uma interlocução entre territórios sonoros, um efeito capaz de produzir desterritorializaçóes a cada entrada e saída das músicas, linhas de fuga que apontariam para fora das demarcaçóes formais, para além dos domínios de um tipo de cinema que segundo os autores deveria ser combatido, um cinema que não sabia a forma de comunicar ao espectador a miséria vivida pelo colonizado, um cinema impregnado de exotismos tropicais, incapaz de expressar a realidade do homem do Terceiro Mundo. ${ }^{9}$ A música "antropofágica" de Villa Lobos e o cancioneiro nordestino reelaborado por Glauber e Sérgio Ricardo ${ }^{10}$ se relacionam diretamente a uma proposta de reinvençáo cultural, que atualizou as formas musicais de matrizes rurais e de matrizes urbanas, buscando afirmar um estilo inovador frente à cultura colonizadora. Essa reinvenção se alinhava aos intuitos de uma Eztetyka que queria provocar tremores nos territórios sonoros fílmicos consagrados pelo espetáculo da cultura de massas. A recusa dos autores do Cinema Novo em figurar uma dada realidade, "transplante da vida autêntica de uma época para o imaginário da tela" ${ }^{11}$, faz da música em Deus e o diabo uma força criativa que atualiza e afirma, na própria textura do som, sua potência inventiva no combate a um projeto cultural dominante. 
Nessa recusa, afirma os princípios básicos da estética da fome, num movimento onde, num só golpe, o estilo cinematográfico se afina às condições de sua produção, marca sua oposição estético-ideológica ao cinema dominante, dá ensejo a que a própria textura do filme expresse o subdesenvolvimento que o condiciona e transforma a sua precariedade técnica, de obstáculo, em fonte da sua riqueza de significaçóes. (XAVIER, 2007, pag. 112).

Na proposta de edição sonora da Eztetika da Fome não havia lugar para o uso da música de forma tradicional, conduzindo a narrativa, codificada ou naturalista. Em Deus e o diabo, numa das sequencias mais celebradas do cinema brasileiro, a dos beijos entre Corisco (Othon Bastos) e Rosa (Yoná Magalhães), encenados como um ritual, que culmina com o sexo dos dois personagens em plano aberto, a música de Villa Lobos além de reforçar as sensaçóes do mundo interior dos personagens, amplifica a força de desterritorialização da sequência, agenciando afetos e relaçóes que transbordam o território sonoro fílmico tradicional e alargam o campo da escuta no cinema, formatada entre outras coisas, pelo uso da música de forma convencional. Um dos efeitos da música de Villa Lobos nessa cena é o de reverter e ampliar a forma de utilização da música no filme brasileiro, que até o surgimento das primeiras películas do cinema novo se limitava a temas orquestrados que buscavam dirigir a emoção do espectador. Glauber usa Villa Lobos e sua erudiçáo incorporada de matrizes sonoras locais para celebrar o beijo exagerado, o sexo nada romântico, entre um cangaceiro e uma camponesa rebelde, afirmando desse modo sua empatia com a proposta estética do compositor, utilizando a sua música não mais como símbolo de um nacionalismo modernizador, mas para provocar um efeito de "paródia revolucionária" do modelo de cinema industrial, que geralmente usa cançóes de forte apelo emocional para selar os momentos e encontros apaixonados entre heróis e mocinhas nos filmes comerciais:

Villa-Lobos talvez fosse quem melhor colocou todo o Brasil em termos de arte: Villa-Lobos filtrou toda uma temática popular, verdadeira, humana, impregnada de nossas tradiçóes, em um forma musical de grande valor. E quando comecei a ouvir Villa-Lobos, fui compreendendo toda a sua importância (ROCHA, 1965, p. 132).

A "Cantilena”, ária das Bachianas Brasileiras n.5 que celebra o envolvimento entre Corisco e Rosa, entre o mito transfigurado do cangaço e a camponesa errante, atravessa-nos a ponto de sentirmos e pensarmos o sertão brasileiro sob a influência de uma sonoridade urbana, vinda do território sonoro erudito, uma erudição que se rebela contra os padrôes formais da música clássica ocidental incorporando influências locais: 
No cinema novo há uma tendência de se fazer filmes onde a música não seja somente um comentário, mas elemento tão importante quanto os diálogos e a fotografia. Eu estava inspirado por Villa-Lobos quando fiz Deus e o diabo. Há uma cena no filme que eu tive a ideia de filmar porque eu havia ouvido a música - é a cena dos beijos - entre Corisco e Rosa. Eu tinha medo de filmar essa cena que era indispensável. Ouvi um disco à noite, a Bachiana brasileira $\mathrm{n} 5$, discuti com o fotógrafo e os assistentes, e nós tivemos a ideia da cena, em seguida fiz a montagem a partir da música, em função do ritmo. (ROCHA, 2004, p. 116).

O uso de Villa Lobos na edição sonora de Deus e o Diabo na Terra do Sol revela o empenho da moderna cultura brasileira em tornar-se independente das influências culturais colonizadoras, no cinema e na música e de ser capaz de expressar-se em sintonia com a singularidade das manifestaçôes culturais locais e com a realidade social e política do subdesenvolvimento. A preocupação em ajustar as intençôes estéticas de uma geração de jovens diretores às vanguardas culturais, que buscaram na reelaboração da forma e dos temas locais uma expressão artística condizente com a realidade é selada com a escolha do sertão nordestino como tema. Um território de tensóes que refletia os desatinos de um país aturdido entre a civilização e a barbárie.

Recusando uma figuração do sertão pautada pelas convençôes do estilo cinematográfico dominante, Glauber Rocha experimenta novas possibilidades para mover as estruturas pré-estabelecidas da montagem fílmica canônica. Um aspecto que ilustra como se deu esse movimento criativo na montagem de Deus e o diabo foi o fato de Glauber aproveitar o processo de pós-produção para realizar experiências. Toda a trilha sonora fora pós-produzida em estúdios de dublagem e sonorização, comuns à época, já que as primeiras tentativas de utilização de som direto em longas-metragens de ficção, no cinema brasileiro, haviam a pouco começado. ${ }^{12}$ Vozes carregadas de dramaticidade, uma mesma voz para dois personagens, como acontece com a voz do ator que interpreta Corisco em Deus e o diabo, Othon Bastos ${ }^{13}$. Tons proféticos, ruídos, sons da natureza, sons de objetos, músicas, todas essas sonoridades inseridas na montagem. O que chama atenção nesse processo não é o seu caráter inovador no sentido técnico, já que essa prática era comum aos filmes brasileiros, o que é importante ressaltar é o modo como o procedimento é transfigurado, modificado, perturbando os estereótipos narrativos, provocando transformaçôes, criando possibilidades de combate. Acionar estratégias para mobilizar o espectador entorpecido pelos territórios sonoros da comercialização, da zona de conforto. Tons da oralidade local são recriados, sobrepostos a outros sons do território sertanejo, que interagem com os do território sonoro urbano, num fluxo de forças afetivas e políticas que ultrapassa os limites da cognição programada. Essa die- 
gese múltipla e heterogênea do som em Deus e o diabo foi construída na pós-produção, o que garantiu um distanciamento maior do momento de captação das imagens. A liberdade criativa para interpretar e associar na montagem os sons às imagens revela-se como uma tática de enfrentamento diante da construção de modos de escuta fílmica convencionais, formatados pela narrativa clássica. Glauber parecia saber contra quais forças expressivas e micropolíticas ele estava lutando, contra quais mecanismos de subjetivação, que através dos fluxos de sons, imagens e informação, veiculados pelo cinema formatado dos grandes estúdios faziam os espectadores consumir seu capitalismo cultural, sua economia virtual, mobilizando-os, explorando-os num nível sutil, fugaz, que escapava ao próprio controle desses regimes de poder, impulsionados a um movimento de permanente atualização de suas práticas:

Através dos fluxos de imagem, de informação, de conhecimento e de serviços que nos chegam ou que acessamos constantemente, absorvemos maneiras de viver e sentidos de vida, consumimos toneladas de subjetividade. Chame-se como se quiser isto que nos rodeia, capitalismo cultural, economia imaterial, sociedade de espetáculo, era da biopolítica, o fato é que vemos instalar-se nas últimas décadas um novo modo de relação entre o capital e a subjetividade. O capital, como o disse Jameson, através da ascensão da mídia e da indústria de propaganda, teria penetrado e colonizado um enclave até então aparentemente inviolável, o Inconsciente. Mas esse diagnóstico é hoje insuficiente. Ele agora não só penetra nas esferas as mais infinitesimais da existência, mas também as mobiliza, ele as póe para trabalhar, ele as explora e amplia, produzindo uma plasticidade subjetiva que ao mesmo tempo lhe escapa por todos os lados, obrigando o próprio controle a nomadizar-se. (PELBART, 2012, p.2).

Para enfrentar os fluxos de subjetividade que o filme de Hollywood e suas réplicas nacionais estavam produzindo, era importante inventar um modo próprio de fazer cinema, penetrando zonas consideradas inaudíveis, rivalizando com essa rede dominante de significaçôes, criando territórios sonoros fílmicos alternativos aqueles ofertados ou mediados pela indústria cultural. Reverter as reterritorializaçóes propostas pela economia de bens culturais que sutilmente estava sendo implantada através do cinema. Apresentar as imagens e os sons da violência social no sertão que o discurso oficial ignorava e escondia, atualizar as vozes dos mitos e da cultura local, usando-os como dispositivos de subjetivação, numa batalha pela transmutação de valores operada nas fronteiras da subjetividade do território fílmico. Em Deus e o diabo, o território sonoro fílmico incorpora vetores da arte sertaneja ao passo que reelabora sua estética, potencializa suas forças, enxertando-as de preocupaçóes políticas. Deus e o diabo encontra na convergência entre a invenção artística, a produção autônoma e a preocupação política, a fórmula 
para subverter o discurso paternalista do projeto de modernização, que justificava a pobreza no campo como atraso e não como consequência de um processo histórico de permanente exploração. O filme de Glauber remixa para o espectador os sons e as imagens da fome, renega um tratamento humanitário e assistencialista dos temas sociais e, ao mesmo tempo, cria independência em relação ao aparato técnico cenográfico dos filmes de estúdio, que não conseguiram manter uma indústria cinematográfica no país. $\mathrm{O}$ autor e sua equipe iniciam uma produçáo nômade, viajam ao sertão nordestino para interpretar os dramas da fome, criam um estilo próprio, inventam uma forma nova, política e possível de fazer cinema.

Os sons do sertão nordestino em Deus e o diabo revitalizam a potência da escuta fílmica e tornam-se um imprevisto dentro do discurso estético cultural dominante. Os silêncios e ruídos da fome e da violência aparecem como expressóes capazes de mobilizar a dimensão sensível do audível, uma estratégia para combater a penetração dos dispositivos sonoros que ampliavam o território da modernidade capitalista e reverter as manobras políticas do Estado que incentivava a entrada do filme estrangeiro no país, no qual a lógica da mixagem sonora é concebida com o intuito de conduzir as sensaçóes do público, criar uma ambiência acústica ilusória, afastar da realidade. Os devires sonoros revolucionários em Deus e o diabo ecoam os sons da fome no sertão que induzem à desterritorializaçóes, subvertem os condicionamentos estéticos, os padróes sonoros edificados e desarticulam a fabricação de modos hegemônicos de operar a escuta no cinema. Mobilizam a matéria sensível dos nossos corpos-ouvidos, fazem a realidade sertaneja ser ouvida como uma zona de forças, um campo plural de vozes e afetos ignorados, de múltiplas sonoridades, de tensôes e conflitos, um sintoma alarmante da fome, do abandono e do colonialismo. Recuperam as matrizes sonoras que compunham a atmosfera da cultura agrária nordestina e seus modos de subjetivação, transfigurando-as, articulando-as aos acontecimentos políticos decorrentes "das grandes crises de consciência e de rebeldia, de agitação e revolução" ${ }^{14}$ que caracterizavam o contexto. Glauber Rocha demonstrava acreditar na transformação através da ação, em uma arte cinematográfica com condiçôes de se envolver, de aproximar-se da realidade sertaneja. Potencializar e dar sonoridade aos fenômenos sociais e culturais, reconhecendo na reação violenta do sertanejo oprimido uma manifestação legítima da fome: "Assim, somente uma cultura da fome, minando suas próprias estruturas, pode superar-se qualitativamente: e a mais nobre manifestação cultural da fome é a violência." ${ }^{15}$

Esse reconhecimento transforma-se numa afinidade, na analogia escolhida pelo diretor para apresentar a sua versão dos conflitos, dos mitos e das manifestaçôes culturais do sertão, expressando-os também de forma violenta. Alarmar a debilidade ética 
e os delírios causados pela fome, a opressão violenta que impossibilitava as mudanças necessárias, a incapacidade do povo de reagir aos regimes de poder que controlavam sua existência, a exasperação do sujeito que atravessado pela crise e pela violência começa a não se reconhecer naquele local, longe e fora dos planos da modernidade conservadora e autoritária.

Para excitar o tema da fome, o território sonoro do sertão em Deus e o diabo emerge prenhe de ruídos e silêncios, tensóes, pausas, repetiçóes, capazes de desestabilizar, causar estranhamento ao expectador. O cinema passa a ser entendido como o lugar de potência e enfrentamento diante dos afetos agenciados pela indústria do consumo. Para descolonizar os ouvidos era preciso evocar a violência social do campo de maneira estética, ressaltar diferenças e ambiguidades, desmontar os mitos da técnica, "tornar distinto e indistinto, claro e obscuro" ${ }^{16}$, gerar afetaçáo para denunciar o paradoxo da fome no sertão.

\section{Do devir sonoro revolucionário}

Glauber, ao referir-se à arte revolucionária proposta pelos seus filmes, chama a atenção para o fato dela ser um imprevisto, impossível de ser entendido pela "razão dominadora". Ao afirmar que a revolução é o "imprevisto dentro da razão dominadora" Glauber inaugura um novo entendimento sobre o que é revolução, subvertendo seu sentido tradicional, segundo o qual o termo remete a fatos históricos que se processam num determinado contexto levando à tomada de poder por parte dos revoltosos, transformando radicalmente o panorama político, econômico e social. Ao falar em "razão dominadora" Glauber quer se referir às noçôes iluministas de política, e é por esse esforço que a revolução remixada pela arte glauberiana constitui o "imprevisto", o que desestabiliza por que é da ordem da "desrazão", do acontecimento, do "mágico", do instante. De maneira extemporânea e espontânea, segundo Anna Lee Rosa ${ }^{17}$ a revolução "eztetyka" glauberiana quebra o pensamento dialético que predomina no contexto da modernidade. Para a Eztetyka da fome apenas uma estética violenta soaria como imprevisto dentro da conjuntura política e cultural que se apresentava no contexto pré-golpe, inspirando um desejo revolucionário em nossas lutas de liberação anticolonialistas. Um devir-eztetyko revolucionário desconectado da razão burguesa, que escaparia à historiografia oficial, incorporado de elementos e afetos da cultura sertaneja e de suas rebeliôes. A estética revolucionária surpreende o espectador acostumado com as formas artísticas consagradas, que nos tornam reféns da razão hegemônica, que passa a ser desmanchada de forma indisciplinada pela experimentação. Inventar uma estética da desrazão mobi- 
lizando formas artísticas antes múltiplas, minoritárias, do que totalizadoras e utilitárias. Ao contrário de representar a revoluçáo, passa a incitar o surgimento de um público que venha a realizá-la, ou nas palavras de Deleuze, de um "povo que falta", e que é devir. O inesperado que surpreende e abala a razão dominadora torna-se devir-revolucionário e não "revolução", "contra-efetuação instantânea", favorável a um pensamento nômade, imprevisível, a uma sensibilidade transitória, flexível, a um modo de escuta nômade. "O devir não é história; a história marca somente o conjunto de condições — por mais recentes que sejam — das quais desviamos para "devirmos", quer dizer, para criarmos alguma coisa de novo." ${ }^{18} \mathrm{O}$ intempestivo que se aparta da história.

A palavra revolução na sua acepção clássica remete a uma noção de evolução histórica que tem uma determinada finalidade. As revoluçóes nesse sentido seriam processos de tomada abrupta do poder, por isso o golpe de 64 por muito tempo foi chamado de revolução.

Deploro o resultado das revoluçóes comunistas. Todas. E, considerando o Terror que se seguiu a 1789, sou cético quanto a revoluçôes em geral. Na maioria das vezes, a violência se dá, não para fazer a história humana caminhar, mas para estancar seu fluxo. (VELOSO, fev. 2014).

Na história da modernidade a palavra "revolução" é resignificada cronologicamente e nos anos de 1960 mediante a crise dos valores políticos e sociais e dos regimes de conhecimento modernos, os sentidos cronológico e evolutivo de revolução dão lugar a outra noção de tempo e de movimento, a do "devir". Para Deleuze as revoluçôes históricas estariam fadadas a um futuro sombrio e só o devir revolucionário seria capaz de nos redimir, de combater o intolerável. ${ }^{19}$

Devir é um conceito filosófico que qualifica a mudança constante, a perenidade de algo ou alguém. Surge primeiro em Heráclito e em seus seguidores na Grécia pré-socrática e regressa com Nietzsche, quando o mesmo apropria-se da noção de eterno retorno como lei do devir. Refere-se à eterna mudança do ontem ser diferente do hoje, a mudança considerada em si mesma, como permanente processo e passagem de um estado a outro. Este movimento, indiferente e contrário ao tempo linear e cronológico favorece a imanente erupção do novo, e desfaz o sentido não só das tentativas revolucionárias de restauração, de um regresso idealizado, como também das revoluçóes em que se proclamam as novidades originais. Num fluxo ininterrupto retornar seria o próprio ser do devir ${ }^{20}$, e todo regresso é sempre diferenciado. Por não mais caber no contexto da pós-modernidade uma busca por situaçôes ideais e não contraditórias, por uma harmonia universal, é que se afirma a multiplicidade, a responsabilidade humana na valo- 
rização da descontinuidade, diante da interação e do confronto constante de diferenças que se afirmam na sua irredutível singularidade. Ao se relacionarem à acontecimentos que tem no mínimo uma via de máo dupla, ao mesmo tempo em que algo vai, algo retorna sobre nós, num sentido sempre paradoxal, indo ao mesmo tempo ao futuro e retornando em direção ao passado, os devires sonoros revolucionários em Deus e o diabo dissolvem os paradigmas de utilização do som no cinema, não assumem uma forma precisa, por serem multiformes, flexíveis, potencialmente subversivos. Rompem com o bom senso e o senso comum da racionalidade em termos estéticos, políticos e artísticos.

\section{Considerações finais}

Do devir sonoro revolucionário em Deus e o diabo emergem sonoridades que, diferente do que possa parecer, náo buscam reviver uma origem ideal, nem apresentam-se com uma finalidade, como a de um telos igualmente ideal. Numa dimensão micropolítica, cada elemento sonoro se constitui e coexiste momentaneamente com outros elementos, fomentando desejos de desenraizamento, de multiplicidade. Uma multiplicidade que estilhaça as fronteiras entre artista e povo. Tanto o pensador quanto o artista têm como função ampliar os limites do pensar e do dizer. Ambos têm como objetivo o movimento, a transformação do pensamento imóvel, a violação do pensamento régio, dominante. Este artista/pensador atuaria como "máquina de guerra”, máquina de metamorfose, que possibilita emergir a diferença. Para compreender a máquina de guerra, Deleuze utiliza o mito do guerreiro Indra, que se opóe tanto a Varuna quanto a Mitra, os deuses da soberania. O guerreiro não se reduz a nenhum desses dois nem forma um terceiro, ele é antes uma "multiplicidade pura e sem medida, uma celebridade contra a gravidade, um segredo contra o público, uma potência contra a soberania" ${ }^{21}$.

Deleuze pensa a máquina de guerra como sendo pura forma de exterioridade, ao passo que o aparelho de Estado constitui a forma de interioridade que tomamos por modelo ou segundo a qual temos o hábito de pensar. Para ele, o guerreiro é aquele que trai tudo, e é como guerreiro que o artista atua quando vai de encontro com a diferença, quando vai em busca do "outro".

\section{$\operatorname{son}$}

\section{NOTAS}

1 Trilogia do Sertáo (Vidas secas -Nelson Pereira dos Santos 1963, Deus e o Diabo na Terra do Sol Glauber Rocha 1963 e Os fuzis - Ruy Guerra 1963) 
2 Ver a participação direta dos EUA no golpe de 64 através do documentário "O dia que durou 21 anos" de Camilo Tavares.

3 Informações extraídas da matéria "Apoio editorial ao golpe de 64 foi um erro" Jornal O Globo, publicado em 31/08/2013.

4 FUGANTI, 2013, p.1

5 Estética criada por Glauber Rocha e depois transformada em manifesto apresentado em 1965.

6 OBICI, 2008

7 DELEZE, GUATTARI, 2005

8 OBICI, 2008, p.53

9 ROCHA, 2004, p.64

10 Sergio Ricardo, músico, compositor e arranjador da nova geração da moderna música brasileira dos anos 60, compóe as músicas e interpreta os versos transformados por Glauber, colhidos dos cegos cantadores do sertáo da Bahia.

11 XAVIER, 2007, p.112

12 COSTA, 2008, p. 132

$13 \mathrm{O}$ ator Othon Bastos que interpreta Corisco foi responsável também pela gravaçáo da voz do beato Sebastião interpretado pelo ator Lídio Silva.

14 ROCHA, 2004, p. 65

15 ROCHA, 2004, p. 63

16 OBICI, 2008, p. 139

17 ROSA, 2011

18 DELEUZE, 1990, p. 2

19 DELEUZE, 1990, p. 2

20 DELEUZE, s/d, p. 39

21 DELEUZE, GUATTARI, 2005, v.5, p. 12

\section{REFERÊNCIAS}

ALBUQUERQUE JÚNIOR, Durval Muniz de. A invenção do Nordeste e outras artes. Recife: FJN, Ed. Massangama; São Paulo: Ed. Cortez, 1999.

DELEUZE, Gilles. [1972-1990] Pourparlers 1972-1990. Paris: Minuit, 1990. Edição bras. Conversaçốes. Rio de Janeiro: Ed. 34, 1998.

O devir revolucionário e as criações políticas. Entrevista de Gilles Deleuze a Toni Negri. Tradução João H. Costa Vargas. Novos Estudos - CEBRAP, n.28,1990.

. GUATARRI, Félix. [1980] Mille Plateaux - Capitalisme et schizophrénie 2. Paris: Minuit 1980. Ed. Bras. Mil Platôs: capitalismo e esquizofrenia. Vol 1, 2, 3 e 4. Rio de Janeiro: Editora 34, 2005.

. GUATARRI, Félix. [1991] Qu’est-ce que La philosophie? Paris: Minuit 1991. Ed. Bras. O que é a filosofia. São Paulo: Ed. 34, 2004.

OBICI, Giuliano Lamberti. Condição da escuta: mídias e territórios sonoros. Rio de janeiro: 7Letras, 2008.

FUGANTI, Luis. Publicação de artigos científicos. Ética como Potência e Moral como

Servidão, 2013. Disponivel em: http://www.luizfuganti.com.br/escritos/textos/68-etica-comopotencia-e-moral-como-servidao

PELBART, Peter Pál. Vida capital: ensaios de biopolítica. São Paulo: Iluminuras, 2003. 
Publicação de artigos científicos. Biopolítica e Biopotência no coração do Império, 2012. Disponível em: http://www2.cultura.gov.br/site/2006/11/15/biopolitica-ebiopotencia-no-coracaodo-imperio-por-peter-pal-pelbart/

ROCHA, Glauber. Revisão crítica do cinema brasileiro. São Paulo, Cosac\&Naify, 2003. Revolução do Cinema Novo. Rio de Janeiro, Alhambra/Embrafilme, 2004.

ROSA, Ana Lee. A missa bárbara rezada por Glauber Rocha num tempo que era proibido proibir. Rio de Janeiro: PUC-Rio, 2011. Tese (Doutorado) - Programa de Pós- Graduação em Letras, Pontifícia Universidade Católica do Rio de Janeiro, Rio de Janeiro, 2011.

VELOSO, Caetano. Publicação de artigos. Diapasão, mar. 2014. Disponível em: http://oglobo.globo. com/cultura/diapasao-11957110

XAVIER, Ismail. Sertão mar: Glauber Rocha e a estética da fome. São Paulo, Cosac Naify, 2007.

\section{Resumo}

O tema central do presente artigo é pensar a utilização dos sons na trilha sonora de Deus e o Diabo na Terra do Sol - Glauber Rocha 1963, a partir das inovaçôes estéticas e dos territórios sonoros diferenciados propostos pelo filme.

\section{Abstract}

The central theme of this article is to think the use of the sounds in the soundtrack of film Deus e o Diabo na Terra do Sol - Glauber Rocha 1963, from the aesthetic innovations and differentiated territories proposed by sound film.

Légua \& Meia Revista de Literatura e Diversidade Cultural
NASCIMENTO, Andrigo de Lázaro S. Casé do. Devires sonoros revolucionários em Deus e o Diabo na Terra do Sol. Légua \& Meia: Revista de literatura e diversidade cultural. Feira de Santana: UEFS, A. 14, nํㅜ 7, 2016, p 22-32.

Andrigo de Lázaro S. Casé do Nascimento é Mestre pelo Programa Multidisciplinar de PósGraduação em Cultura e Sociedade (Pós-Cultura/ UFBA) e membro do Grupo de Pesquisa Nomos - Culturas, Poderes e Subalternidades (Pós-Cultura/ UFBA). 